\title{
Measures to Protect Patient Rights by Monitoring the European Pharmaceutical Market
}

\author{
Cristina-Luiza Erimia
}

Ovidius University of Constanta, Faculty of Pharmacy, Campus Corp B, University Alley No. 1, Constanta, Romania

Rodica Sîrbu

Corresponding author, sirbu_27@yahoo.com

Ovidius University of Constanta, Faculty of Pharmacy, Campus Corp B, University Alley No. 1, Constanta, Romania

Melat Cherim

UMF Carol Davila Bucharest, Faculty of Pharmacy, Str. Traian Vuia No. 6, Sector 2, Bucharest, Romania

Stelian Paris

Ovidius University of Constanta, Faculty of Pharmacy, Campus Corp B, University Alley No. 1, Constanta, Romania

\begin{abstract}
The pharmaceutical sector is vital to the health of European citizens, who must have access to innovative, safe and affordable medicinal products. The operation of the pharmaceutical sector at Community level is based on four dimensions: regulation, integration, competition and innovation. Given its importance for health services, the existing regulatory framework in this area should not include unnecessary regulatory constraints restricting and limiting competition. Considering this fact, this article analyzes the existing control in competition law on the pharmaceutical market achieved at EU level. Currently, the free movement of goods is regulated by many policies and harmoniously fits within a responsible domestic market, which guarantees the unimpeded access to high quality products and provides a high degree of protection of other objectives of public interest. Given the fact that medicinal products are commodities, this article examines how, by monitoring the pharmaceutical market, patients are guaranteed the right to high quality medicines. This paper also aims to present the complex mechanisms of the pharmaceutical sector that have undergone a careful and consistent analysis both the European Commission and the Competition Council.
\end{abstract}

Keywords: European competition law, the pharmaceutical sector, patients' rights, high quality drugs, research and innovation, generic drugs, competition at the level of the European Union

\section{Introduction}

Before establishing a Community code relating to medicinal products for human use [1], trade in medicinal products within the European Union was hindered by disparities between certain national provisions which directly affect the functioning of the internal market. To reduce disparities in medicines for human use was necessary to approximate the relevant laws, establishing rules for monitoring medicines and specifying the obligations of the competent authorities of the Member States to ensure compliance with legal provisions. In this regard, Directive 2001/83/EC represented an important step in achieving the objective of free movement of medicines. 
Regarding regulation, concerns at European level regarding competition on the pharmaceutical market pay particular attention to the rules on marketing authorization, on the pricing and reimbursement of medicinal products, as well as rules on patents.

At EU level there are legislative initiatives aimed at creating a favorable business environment for research and innovation and promoting the competitiveness of the pharmaceutical sector.

On average, consumers have no access to generic drugs earlier than seven months after the innovative drugs have lost exclusivity. This is due, in part, to pharmaceutical companies that use various techniques to extend the commercial lifecycle of their products.

When the original products enter into competition with generic drugs, prices drop and they become accessible to a larger number of patients. In some cases, prices may decrease considerably.

The European Commission aims to ensure safe, effective and affordable to patients in Europe and to create at the same time a business environment that stimulates research, encourages important innovation and supports the competitiveness of the industry.

\section{Theory}

The European Commission aims to provide safe, effective and affordable medicines for European patients and to create, at the same time, a business environment that stimulates research, encourages important innovation and supports the competitiveness of the pharmaceutical industry.

Given the acquired experience, especially by the Committee for Proprietary Medicinal Products, in the removal of remaining barriers to the free movement of proprietary medicinal products, additional legislative measures amending the Community code relating to medicinal products for human use have been necessary [2].

Consumers do not have access to generic medicines, on average, earlier than seven months from the date on which innovative medicines have lost exclusivity (which is partly due to pharmaceutical companies that use various techniques to extend the commercial life cycle of their products). When the original medicines compete with generic products, prices drop, in some cases considerably, making the products accessible to a greater number of patients.

Given the importance of an effective pharmaceutical sector and the presence of some indications that it may be possible that in the European Union, competition on the pharmaceutical market may not be functioning properly, the European Commission launched an investigation in the pharmaceutical sector on 15 January 2008 [3]. The investigation was aimed at analyzing particularly the reasons for the delays in market entry of generic drugs and the apparent decline in innovation, measured in the number of new drugs entering the market. Sector analyses allow the Commission to collect information for the application of Articles 81 and 82 of the Treaty of the EC.

Taking into account that sector investigations are a tool having as legal basis the European competition law [4], the main focus is the behavior of the companies. The investigation focused on the practices the companies may use in order to block or delay generic competition, as well as to block or delay the development of competing innovative products.

The investigation focused mainly on the competitive relationship between innovative has and generic companies, as well as on the competition between innovative companies. To perform a thorough analysis, the European Commission selected 43 innovative companies and 27 generic companies representing $80 \%$ of the relevant turnover of the EU and, in general, are larger companies, active in several Member States.

\section{Results and Discussions}

In 2005 entered into force significant changes to the regulatory framework in the pharmaceutical field, which had the objective of facilitating market entry of generic drugs [5], for example the introduction of the so-called Bolar provisions [6]. 
Before the introduction of the Bolar provision within the EU regulatory framework, the development of the patent before its expiry was not regulated at EU level. Therefore, generic drug manufacturers have developed products conducted the related testing in countries where the basic patent had already expired or where there was no such protection, outside the EU, in European countries where there was a Bolar type provision or in other EU member states where experimental work was permitted in certain cases.

The new harmonized rules on the data exclusivity and marketing practically entered into force only in 2013 , because of the application of the new protection periods for innovative products for which a permit was requested and which were authorized after these rules became effective, in 2005.

In accordance with the decision for opening, the investigation did not address in detail neither any deficiency in the distribution chain, which are subject to a separate market monitoring [7], nor the competition between generic companies, which generally occurs at the level of the prices, because the setting of prices and/or the arrangements on market shares are not covered by Article 81 of the EC Treaty.

The European Commission for the pharmaceutical sector uses its full powers conferred to it under antitrust rules (Articles 81,82 and 86 of the EC Treaty), the control of economic concentrations [8] state aid control (Articles 87 and 88 of the EC Treaty). Whenever the interest of the European Union will impose it, the European Commission, in close cooperation with national authorities for competition, will investigate any breach of regulations in the pharmaceutical sector. Also, measures may be taken at national level in areas that have not been targeted in particular investigation or are outside its scope.

Intellectual property rights promote dynamic cooperation by encouraging companies to invest in developing new or improved processes or products. Competition has a similar role, encouraging enterprises to innovate. Therefore, both intellectual property rights and competition are necessary to promote innovation and to ensure that it is used in competition conditions [9]. If the existence and exercise of an industrial property right is not in itself incompatible with the right of the competition, they are not excluded from the application of competition law [10]. However, certain practices may constitute a violation, only in exceptional ircumstances [11].

In the past, the Commission and national authorities have already taken action in several cases for specific infringements of competition law in the pharmaceutical sector. Among the decisions taken are: fines imposed by the UK competition authority against a pharmaceutical company for selling its products at very low prices to hospitals and at very high prices to patients, through pharmacies; this strategy could be applied as it was found that doctors are influenced by the brands used in hospitals (NAPP case) [12]; provisional measures taken by the French competition authority for a generic company whose products were constantly criticized by sales staff of an innovative company, even after obtaining the marketing authorization (the Arrow Génériques case) [13]; the decision of the Italian competition authority, which determined that the denial of an innovative company to grant license for the production of an active substance, which the manufacturers of generic drugs needed to penetrate the national markets where the innovator had no exclusive rights, constituted a violation of Article 82 of the Treaty (Case GSK) [14].

Regarding the competition between innovative and generic companies, the delay in market entry of generic drugs is an issue of particular concern. The possible use of specific instruments by innovative companies to delay the market entry of generic drugs will be subject to the control competition, if this use has an anti-competition character, which may constitute an infringement under Article 81 or 82 of the EC Treaty.

We believe that the agreements are designed to blocking the market entry of competition may constitute infringements of European competition law. Settlement agreements that restrict the market entry of generic drugs and include a transfer of value from an innovative company to a generic company, or to several such companies, are an example of agreements that may have an anticompetitive nature, especially if the reason behind their conclusion is the division of profits via payments from innovative to generic companies, in detriment to patients and public health budgets.

As a result of the developments in information and communication technologies, goods are now increasingly marketed domestically often through these channels. Therefore, it is not surprising that the role of Article 34 TFEU [15] in Internet 
transactions involving the transfer of goods from one Member State to another has led to calls for action before the Court of Justice.

Issues of this type have appeared in national procedures of a Member State on Internet sales of medicinal products for human use. The law at that time prohibited the sale by mail order of medicinal products, which could be sold only in pharmacies.

The supervision of rules governing and ensuring the freedom of competition on the pharmaceutical market and the direct and unambiguous intervention violations of the regulatory framework are found, guarantees the existence of a competitive environment in the pharmaceutical sector at the level of the European Union.

Article 114 TFEU gives the EU legislative powers to "adopt the measures for the approximation of the provisions laid down by law, regulation or administrative action in Member States which have as their object the establishment and functioning of the internal market". The scope of this provision has been interpreted broadly by the Court [16].

Analyzing the case law of the Court of Justice, it can be considered that the boundary area on tobacco advertising [17] was notable, the Court finding that the EU legislature passed laws that contravene EU law. In the examination of the validity of the contested directive, the Court held that the measures referred to in Article 114 TFEU aimed at improving conditions for the establishment and functioning of the internal market. In addition, if the conditions for invoking Article 114 TFEU are met, "Community legislature cannot be prevented from relying on that legal basis on the ground that public health protection is a decisive factor in the choices to be made" [18].

The Court examined the validity of that Directive in two respects. First, to verify whether the Directive actually contributed to eliminating obstacles to the free movement of goods and freedom to provide services. Secondly, it examined whether the directive contributed to eliminating distortions of competition.

\section{Conclusions}

Any action of the of public authorities in the pharmaceutical sector should aim at creating a competitive environment, which ensures the access of European citizens to innovative, safe and affordable medicines, without unnecessary delays. In this respect, both competition law enforcement and regulatory measures may improve the functioning of the market for the benefit of consumers and must be considered in this regard.

The tendency towards an increased concentration of the market is carefully monitored by the Commission and in the analysis of these cases of economic concentration will be used the knowledge obtained following the sector investigation, to maintain a competitive structure and process on the market.

Promoting innovation and stimulating the increase of economic growth are common goals of intellectual property law and competition law. Innovation is a key and dynamic component of an open and competitive market economy.

Particularly with regard to the competition between innovative companies, the defensive patent strategies aimed primarily at excluding the competition without pursuing innovative efforts and / or the refusal to grant licenses for unused patents will still be subject to control, especially in the cases in which innovation was truly blocked.

Following the European Commission's sector investigation, all the stakeholders strongly endorsed the immediate creation of a single Community patent [19] and of a unified and specialized system for solving disputes [20] in Europe, which are currently under discussion.

The Commission is committed to developing an EU pharmaceutical framework for the $21^{\text {st }}$ Century, which promotes innovation, especially in areas where there are outstanding medical needs [21].

At EU level there are legislative initiatives designed to create a business environment that promotes research and innovation and the competitiveness of the pharmaceutical sector. 
On average, consumers do not have access to generic medicines earlier than seven months after the date on which the innovative medicines lost exclusivity. This is due, in part, to pharmaceutical companies that use various techniques to extend the commercial life cycle of their products.

When the original products compete with generic medicinal products, prices go down and become accessible to a larger number of patients. In some cases, prices may decrease considerably.

Any action of public authorities in the pharmaceutical sector should aim at creating a competitive environment to ensure the access of EU citizens to innovative, safe and affordable medicinal products, without unnecessary delay. In this respect, both competition law enforcement and regulatory measures can improve market performance for the benefit of consumers and should be considered in this regard.

\section{References}

[1] Article 10 item (6) of Directive 2001/83/EC of the European Parliament and of the Council of 6 November 2001 on the Community code relating to medicinal products for human use (JO L 311, 28.11.2001, p. 67) modified by Directive 2004/27/EC

[2] Article 17 item (1) first paragraph of the Council Regulation (EC) No 1/2003 of 16 December 2002 on the implementation of the rules on competition laid down in Articles 81 and 82 of the Treaty, JO L 1 of 4.1.2003

[3] Case C-376/98 Germany/The Parliament and the Council (tobacco advertisement), Rec. 2000, p. I-8419. This case refers to the validity of Directive $98 / 43$ on the approximation of the laws, regulations and administrative provisions of the Member States relating to the advertising and sponsorship of tobacco products.

[4] Case C-376/98 Germany/The Parliament and the Council, Rec. 2000, p. I-8419, paragraph 88.

[5] Commission Decision of 15 January 2008 initiating an inquiry into the pharmaceutical sector pursuant to Article 17 of Council Regulation (EC) No 1/2003 (Case No COMP/D2/39.514).

[6] Commission Staff Working Document on Market Monitoring: State of Play and Envisaged Follow-Up, available at: http://ec.europa.eu/economy_finance/publications/publication13688_en.pdf; see also the Commission Staff Working Document on "The Single Market Review: one year on", available at: http://ec.europa.eu/internal_market/strategy/docs/smr_oneyear_en.

[7] Communication from the Commission of 16 July 2008 on An Industrial Property Rights Strategy for Europe, $\operatorname{COM}(2008) 465$ final.

[8] Council Regulation (EC) No 139/2004 of 20 January 2004 on the control of concentrations between undertakings, JO L 24 din 29.1.2004, p. 1-22.

[9] Decision of Autorità Garante della Concorrenza e del Mercato of 8 February 2006, no. 15175 (case A363 Glaxo-PRINCIPI ATTIVI), available at: http://www.agcm.it/.

[10] Decision of the Director General of Fair Trading no. CA98/2/2001 of 30 March 2001, NAPP Pharmaceutical Holdings Limited and Subsidiaries (NAPP), available at: http://www.oft.gov.uk/shared_oft/ca98_public_register/decisions/napp.pdf).

[11] Directive 2001/83/EC, of the European Parliament and of the Council of 6 November 2001 on the Community code relating to medicinal products for human use, published in the Official Journal of the European Union $\mathrm{L}$ 311 of 28.1.2001. The consolidated version was published in the Official Journal of the European Union L 87 of 31.3.2009. 
[12] Directive 2004/27/EC of the European Parliament and of the Council of 31 March 2004 amending Directive 2001/83/EC on the Community code relating to medicinal products for human use, JO L 136, p. 34, special edition, 13/vol. 44, p. 116.

[13] EC Communication Guidelines on the application of Article 81 din of the Treaty to categories of technology transfer agreements, JO C 101 din 27 April 2004, p. 2-42

[14] Judgment of the Cour de Cassation of 13 January 2009, Pourvoi no. P 08-12.510 (press release available at: http://www.conseil-concurrence.fr/user/standard.php?id_rub=211\&id_article=865).

[15] Judgment of the Court of 27 September 1988, case 65/86 (Bayer/Süllhöfer), Rec., 1988, p. 5249.

[16] See, for example, Case C-350/92 Spain/The Council, Rec. 1995, p. I-1985, and Case C-300/89 Commission/the Council (titanium dioxide), Rec. 1991, p. I-2867.

[17] See, for example, Directive 2004/27/EC of the European Parliament and of the Council of 31 March 2004 amending Directive 2001/83/EC on the Community code relating to medicinal products for human use, published in the Official Journal of the European Union L 136 of 30.4.2004.

[18] The Final conclusions and recommendations of the Pharmaceutical Forum, available at: http://ec.europa.eu/pharmaforum/docs/final_conclusions_en.pdf

[19] The proposal for a Council Regulation on the Community patent can be found in the working document of the Council no. 8588/09 of 7 April 2009, available at: http://register.consilium.europa.eu/pdf/en/09/st08/st08588.en09.pdf.

[20] Treaty on the Functioning of the European Union (consolidated version), published in the Official Journal of the European Union (OJEU) C 326 of 26 December 2012.

[21] Working document of the Council no. 7928/09 of 23 March 2009, available at: http://register.consilium.europa.eu/pdf/en/09/st07/st07928.en09.pdf. 